Lonise O. Vasvári

Stony Brook University

\title{
Szerepjátszás és identitás Fehér Lili 1945-ben megjelent, Nem ér a nevem: egy szökött zsidó naplója címü múvében
}

\section{Bevezetés}

Még mindig nagyon keveset tudunk a közvetlenül a háború után publikált, magyar szerzőségủ visszaemlékeezés-irodalomról, és különösen a még a magyar szakirodalomban is méltatlanul elhanyagolt, nők által írott alkotásokról. A legtöbb női szerző csak mérsékelt korabeli recepciónak örvendett, mely a legjobb esetben is alig terjedt túl a közvetlenül érintettek körén. Mûveik a kulturális emlékezetből viszonylag gyorsan kitörlődtek, néhány irodalomjegyzékbe esetleg bekerültek, de példányaik hamar elfogytak vagy nehezen beszerezhetôvé váltak még Magyarországon is. Egyikük sem került be a magyar holokausztkánonba, amikor az jó harminc évvel később formálódni kezdett, és még kevésbé a nemzetközi holokausztkánon és diskurzus katalógusába. Irodalmi szemszögből nézve az első túlélôemlékiratokat időnként pejoratívan élményirodalomnak címkézték, ami annyit tett, hogy nem irodalmi szerzők, hanem újságírók vagy hétköznapi emberek írták őket, és ezért a szenzációhajhász ponyvairodalomhoz hasonlóként kerültek megítélésre.

Mindezek ellenére van mit tanulni ezekből a korán megjelent művekből. Részben azért, mivel az, hogy mire emlékszünk a múltból, sokban összefügg azzal, hogy mikor emlékezünk: a közvetlenül a háborút követő időszak, amikor az emlékezést még nem homályosította el az idő, és még nem befolyásolták a későbbi olvasatok, pontosabb leírását adhatja a szerző élményeinek. A szerzőknek ekkor még a magyar államszocializmus idejét jellemző, későbbi ideológiai elvárásoknak sem kellett megfelelniük, ahogy a nyugati holokausztdiskurzus gyakran érzelgős, a túlélők későbbi boldog életének bemutatására kihegyezett kanonikus elvárásainak sem. Ehelyett ezeket a korai mûveket a sürgősség érzésével írták, hogy megértsék és rögzítsék a közelmúltat, és hogy a szerző megküzdhessen saját, személyes élményeivel, egy olyan időszakban, amikor még nem volt idő arra, hogy a 
fizikai és lelki sebek elkezdjenek begyógyulni, és amikor a „holokauszt” szó, ahogy azt ma világi értelemben értjük, sem volt még közhasználatban.

A legelső háborús idôkbeli dokumentarista írásokat, amelyek különféle alműfajokba voltak sorolhatók - akadt köztük emlékirat, tanúságtétel (időnként interjú formájában), riport, dokumentumregény -, igen vegyes kulturális hátterű és osztályhelyzetű szerzők írták. ${ }^{1}$ Mivel a közvetlenül a háború után keletkezett írásokat hajlamosak voltak történeti dokumentumokként katalogizálni, ezért gyakran figyelmen kívül hagyták kreatív írásmú jellegüket. És csakugyan, ezen művek legtöbbje nem tartott igényt arra, hogy irodalomként olvassák. Ezeknek a marginalizált történeteknek a gender-központú olvasata bepillantást nyújthat abba is, hogy a társadalmi nem milyen nagy hatást gyakorolt a háborús traumás élményekre. Végezetül, ezek a múvek azért is megérdemlik, hogy tanulmányozzuk óket a saját kulturális miliőjükön belül, mivel a közvetlenül a háború után született holokauszt témájú írások, amik csakis magyarul érhetők el, mindmáig nagyrészt elérhetetlenek a szélesebb holokausztkutatások számára.

Jelen tanulmány egy nagyobb, folyamatban lévő, kritikai kultúrakutatás- és gender studies-fókuszú kutatásomnak, a Women Writing Holocaust: Lives and Beyondnak a része, ami több száz nő különféle nyelveken írott élettörténetírásait valamint ezeknek a nőknek a társadalmi nemükkel kapcsolatos [gender-related] élményeit vizsgálja a második világháború és a holokauszt ideje alatt. ${ }^{2}$ Célom az, hogy jobban értékeljük a női élettörténetírások nyújtotta tanúságtételeket és elismerjük összetettségüket, ahogy a hallgatásukat is arról, ami elmondhatatlan. Míg a nyugati államok túlélőinek és azoknak a szerzőknek az írásmúvei, akik a felszabadulás után Nyugatra emigráltak, bizonyos mértékig már részét képezik a Nyugat politikai tudatának, szeretném hangsúlyozni annak szükségességét, hogy ezt a szövegkorpuszt ki kell egészíteni azokkal a nemzetközileg láthatatlan írásművekkel, amiket „kisebb” nyelveken írtak a korábbi Kommunista Blokk női szerzői.

A kutatásom egyik konkrét célja, hogy rehabilitáljon féltucat figyelmen kívül hagyott vagy elfelejtett múvet, amik a magyar visszaemlékezéé-irodalom körébe tartoznak, és amiket nők írtak magyarul, és Magyarországon is publikálták őket 1945-ben és 1946-ban. Ezek Fehér Lili Nem ér a nevem: Egy šökött zsidó naplója (1945); Izsáki [Izsáky] Margit Ország a keresztfán (1945); Sz. Palkó Vilma A német halálgyárake (1945); Frank Erzsébet 365 nap. Versben irt vallomás a poklok tüzéboól (1946); Molnár Hegedüs Anna [Hegedüsné Molnár Anna] Miért? (1946); és Gács Teri $A$ mélységböl kiáltunk hozzád (1946) címú mûvei. Ezeknek a nôknek egyike sem volt semmiféle ellenállási mozgalom

${ }^{1}$ Az életírás, társadalmi nemek és trauma témáiról lásd még Vasvári 2016, a jelen szaklapban.

2 A kutatási terület eredményeinek legfrissebb összegzéséhez lásd Kaplan 2019. 
kulcsfigurája, vagy táboriorvos vagy internált kommunista, ellentétben a nyugati nyelven megjelent korai művek szerzőinek némelyikével. ${ }^{3}$ Inkább azokhoz a - zsidó és nem-zsidó - nőkhöz hasonlíthatók, akiknek az 1944-ben írott budapesti háborús naplóiról már írtam korábban ebben a lapban (Vasvári 2017).

A jelen lap megszabta terjedelmi korlátokból adódóan itt csak a korábban említett nôk egyikének, Fehér Lilinek a művét tárgyalhatom. Míg a fentebb felsorolt nők közül többen a deportálásukról és a koncentrációs táborbeli élményeikről írtak, Fehér arról írt, mi történt Budapesten 1944-ben, ahol folyamatos rettegésben élt, hamis papírokkal bujkálva. Azon kívül, hogy Fehér 1945-ös, közvetlenül a háború után megjelent emlékiratát elemzem, amit ezekről az élményeiről írt, arra is kísérletet teszek, hogy legalább töredékeiben rekonstruáljam - ami időnként anekdotikus részletek sorának tűnhet - korábbi személyes és szakmai életét, valamint a társadalmi nem szempontjából is kódolt én-identitását [gendered self-identity] a két világháború közti Magyarország küzdelmes politikai körülményei közepette.

A háború elvesztése után Magyarország politikai, társadalmi és gazdasági struktúrái romokban voltak; az 1945 és 1948 közti időszakban az újjáépítés a háború utáni idők traumái és bizonytalanságai közepette indult meg. Amint azt Kovács András (1984) hangsúlyozza a magyarországi háború utáni zsidóságról írott tanulmányában, míg az 1945-1948-as évek publikációiban az úgynevezett zsidókérdés és a zsidók kiirtása gyakori téma volt, 1948 után már senki nem beszélt a zsidókról. A Rákosi- és Kádárkorszakban az ilyen témájú múvek, ha megjelentek is, antifasiszta irodalomként lettek elkönyvelve, lágertémaként vagy felszabadulási irodalomként, ahol a holokauszt is a korszak sajátos metanarratívájának lett alárendelve, azaz a szocialista és a kapitalista világrend közti küzdelemnek (György 2010; Petri 2015, Kisantal 2018, Jablonczay 2019).

Czibor János már 1945 októberében úgy ítélte meg, amikor egy sor baloldali perspektívából íródott frissen megjelent könyvet bírált, hogy ezeknek a könyveknek a megjelentetése az akkori komoly papírhiány idején puszta forráspazarlás, és míg elismerte, hogy érthető, hogy az emberek úgy érzik, el kell mondaniuk a történetüket, negatívan itélte meg azt, hogy a múvek a múlt borzalmaira összpontosítanak, ahelyett, hogy az új jövő ígéreteivel foglalkoznának. Pándi Pál (1954: 167), noha maga is tábori túlélő volt, ezeket a múveket, amik a háború után állítólag ellepték a könyvesboltokat, még inkább reakciósnak ítélte, mint Czibor, és azon az alapon kritizálta őket, hogy „rikító és művészileg ugyancsak selejtes” művek, mondván, a felszabadulás, mint nagy történelmi forduló témája helyett arra koncentrálnak, hogy az apokaliptikus borzalmakat és a szerzők egyéni sorsát írják meg. A későbbi

${ }^{3}$ Vö. pl. Vasvári 2012, a tábori orvosnők visszaemlékezéseiről. 
szélesebb körű európai holokausztkutatásokkal való összehasonlítás gyanánt érdemes megjegyezni, hogy Annette Wieviorka nagy hatású, L'ère du témoin [A tanú kora] (1998) címú mûvében szintén azt állította, hogy Franciaországban is telítettségérzetet és a megértés hiányát eredményezte az, hogy közvetlenül a felszabadulás után számtalan szemléletesen részletező visszaemlékezés jelent meg. Eric Sundquist (2012: 210), aki David Cesarinivel együtt szerkesztette az After the Holocaust: Challenging the Myth of Silence-t [A bolokauszt utan: A csend mitoszának elvitatása], meggyőzően tekinti át a háború utáni idők gazdag irodalmi termését, de, ami a magyar műveket illeti, elkerülhetetlenül csakis két romániai-magyar nő emlékiratát említi, Lengyel Olgáét és Perl Giselláét, amik egyaránt angolul jelentek meg. De Sundquist fontos felismerést fogalmaz meg, amikor megjegyzi, hogy nehéz lehetett értelmet találni ezekben a nagyon felkavaró múvekben, amikhez akkoriban nem volt értelmezési keret, és ezért „a fontosságuk nehezen megfogható maradt.”

Nemrégiben a magyar tudományosságban is megjelent több tanulmány is ezen visszaemlékezés-irodalom korai múveiről, de ezek a tanulmányok főleg azzal foglalkoztak, hogy férfiszerzőségú szövegekről bebizonyítsák, hogy igenis vannak irodalmi értékeik. Szép Ernőt és Zsolt Bélát visszatérően említik, kevésbé gyakran Nyiszli Miklóst, Fenyő Miksát és Márai Sándort, de az általam korábban felsorolt nők közül a legjobb esetben is csak néhány tünik fel egy-egy lábjegyzetben vagy bibliográfiában. Kálmán C. György (2007) arra mutat rá, hogy a közvetlenül a háború után megjelentetett múvek legtöbbje nem törekedett az irodalmi mú státuszára, és a legtöbbjük nem is volt irodalom vagy jó irodalom, Kálmán C. azokra a múvekre koncentrál, amiknek irodalmi értékük van, és kevésbé azokra, amik legfeljebb dokumentumértékkel bírnak. Elismeri, hogy fontos, hogy fontolóra vegyük, van-e bármi sajátossága annak, ahogy a nők írnak a holokausztról, de az 1960as évek női költészetére koncentrál. Földes Anna (2007) mintegy egytucat nöi szerző nevét sorolja fel, szintén nagyrészt a hatvanas évekből, de rövid áttekintése nem törekszik másra, mint hogy tanúsítsa létezésük fontos tényét. György Péter (2010) már kanonizált férfiszerzőket, Kassák Lajost, Déry Tibort, Szép Ernőt és Zsolt Bélát tárgyalja, hozzátéve, hogy a holokauszttal kapcsolatos írásaiknak évtizedeken keresztül csak nagyon másodlagos szerep jutott az életmúveikben. Márkus Béla (2015) szintén négy férfiszerzőnek a holokauszttal kapcsolatos naplószerü írásait tanulmányozza, szintén Déry-t és Kassákot, továbbá Darvas Józsefet és Nagy Lajost, és felsorolja még Szépet, Zsoltot és Asztalos Istvánt is mint további figyelemre méltó szerzőket, de egyetlen női szerzőt sem. Márkus kiemeli, hogy a szerzők egyike sem írt igazából a háború kezdetéről, hanem mindegyikük csak valamikor 1944-ben kezdte el az írást. Ez az oka annak, hogy Márkus a műveket ostromnaplónak vagy pincenaplónak hívja, így emelve alműfajjá a megírás helyét és idejét. 
Zombory Máté (2015) a Magyar Golgota nyolckötetes gyújteményét vizsgálja, melynek darabjai mind 1945-ben jelentek meg, azzal a céllal, hogy a közelmúlt katasztrófáját bemutassák. Zombory hangsúlyozza, hogy nem az irodalmi értékük alapján kell megítélnünk a köteteket, hanem a szociológiai és kulturális jelentésük alapján. Laczó Ferenc négy zsidó vagy zsidó származású és három nem-zsidó szerzôt vizsgál, akik a deportálásukról írtak, és a múveik mind 1945-1946-ban jelentek meg. Laczó találóan jegyzi meg, hogy munkájának legnagyobb hiányossága minden bizonnyal a női szerzők hiánya (2016, 136 lábj. 9). Kisantal Tamás (2016) arra törekszik, hogy bemutassa, hogy nem igaz, hogy a háborút követô években általános hallgatás volt, hanem ehelyett rengeteg mú jelent meg, amikre jól illett a pejoratívan élményirodalomnak nevezett címke, amin a túlzৃottan kitárulkozó, önéletrajzi ibletésü müveket értették, és amely művek hajlottak a szenzációhajhászásra, és ezért nem felelnek meg a mai elvárásoknak $(53,86)$. Kisantal rámutat, hogy amirôl a nemzetközi holokausztkutatások elfeledkeztek, az az, hogy a szövegeket a saját kulturális kontextusukon belül vizsgálják. Magyarország esetében az elméleti diszkusszió igazán csak a Sorstalanság (1975) megjelenése után kezdődött, de még inkább Kertész 2002-es Nobel-díja után, ezért a korábbi mûvekkel egyszerűen nem foglalkoztak vagy a Sorstalanságon keresztül közelítettek hozzájuk. Fontos megjegyzése, hogy ezek a korai múvek képesek megcáfolni a későbbi elméletet, vagy épp ellenkezőleg, megelöri $[k]$ ötven évvel. Azonban ő sem tárgyal női szerzőket.

\section{Fehér Lili (1899-1948), a „legcsúnyább pesti színésznő”}

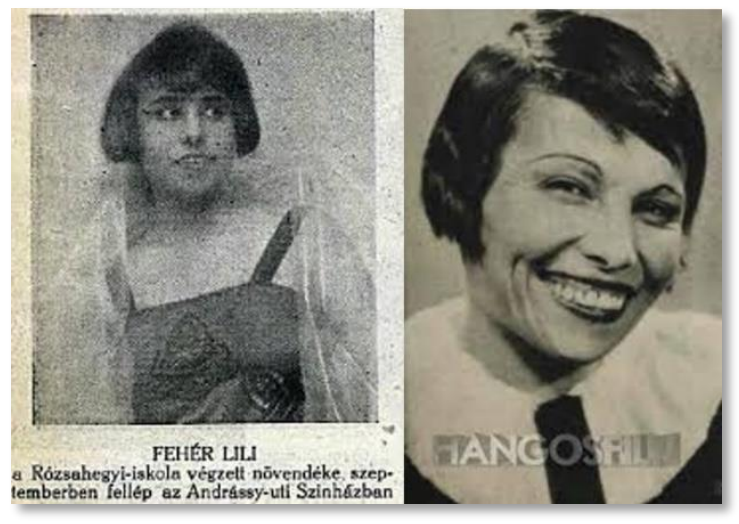

Fehér Lili 1922-ben, huszonhárom évesen, első szerepében; és 1933-ban (Színházi Élet $1933 / 4)$

Fehér Lili Klein Liliként született a budapesti Terézvárosban, jómódú szülők egyetlen gyermekeként. Állítása szerint kora gyerekkora óta színésznő szeretett volna lenni, és 1922-ben el is végezte a híres színész, Rózsahegyi Kálmán Nemzeti Színházbéli sqiniiskoláját. Fehér komika volt, és sosem akart vidéken játszani, ahogy akkoriban erre sok-sok fiatal színésznő rákényszerült, 
és eleinte sikerült is színpadra kerülnie több budapesti színházban is. Alakításaira nagyon pozitív visszajelzések érkeztek, de sosem kapott elég szerepet, és mindig nagyon nehezen tartotta fenn magát. Két rövid házassága volt, az első 1917 és 1921 közt Fehér Imrével, egy kereskedővel, a második pedig 1923 és 1929 közt a hozzá hasonlóan zsidó Peti Sándor (1898-1973) komikusmúvésszel. Azonban a legtartósabb érzelmi kötelék, úgy tűnik, a pulikutyákhoz füzte, akik közül egyet még az 1944-ben kezdődő bujkálása idején is sikerült magánál tartania.

A harmincas években

Fehérnek a színházi munkáin kívül volt néhány nagyon kicsi filmszerepe is, amikben mindig a nem szép nő komikus vagy karakterszerepét vitte, úgy, hogy a neve időnként még a stáblistán sem szerepelt. Játszott a Vica a vadevęösben (1933), a Rothschild leányaban (1934), a Mámıban (1937), és a 300.000 pengö az, utcán címú filmben is (1937).

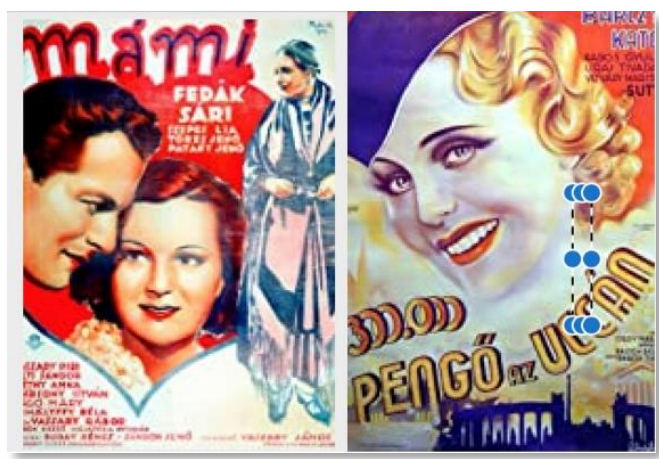

A Mámi (1937), és a 300.000 pengó az utcán (1937), két film, amiben szerepelt Fehér Lili

Ezek közül a Vicát, ami ugyan egy bugyuta szkeccsfilm, de a Hacsek és Sajót játszó híres eredeti színészpáros és néhány operettszám is szerepel benne, nagyon is érdemes megnézni a Budapestről készült felvételek miatt. A film azért is fontos, mivel Gaál Béla (1893-1945) rendezte, akit később Dachauban gyilkoltak meg, és aki az első magyar hangosfilmet, a Csak egy kislány van a világont, továbbá a híres Meseautót is készítette. 1933-ban a Vicát a katolikus Magyar Kultúraban Deák-Bárdos György megkritizálta, mint annak példáját, hogy milyen rossz irányba halad az akkor szárnyait bontogató hangosfilmipar Magyarországon. A mesterkélt parasztábrázolást kifogásolta a filmben, a zsidó kabarévilágot és a zsidók uralta Erzsébetváros és Terézváros helyszíneit, miközben fájlalta, hogy a magyar lelkiségü filmek gyártására meg nincs anyagi támogatás.

Mivel Fehér folyton szenvedett az anyagi nélkülözéstől, az egyik ötlete, hogy előremozdítsa a karrierjét, az volt, hogy úgy reklámozta magát, mint aki a legcsinnább pesti szinésznó. 1932-ben, hogy kicsit több pénzhez jusson, azzal az ötlettel állt Fenyves Dezső, a híres Fenyves rubakelme és fehérnemú árubár. tulajdonosa elé, hogy egy olcsó kötött ruha két külön verziójában fog modellt állni egy sor hirdetésben a Pesti Napló képes melléklete és a Színhári Élet számára, a következő képaláirással: „A legcsúnyább pesti színésznő, Fehér Lili is csinos ebben a kötött-ruhában, melyet 13 pengő 80 fillérért vásárolhat a Kálvin-téri Fenyves-féle Áruházban.” (1941-ben Fenyves még maga vezette 
az áruházát, amint arra az ultrakonzervatív Magyarság panaszkodott is az április 20-ikai száma 3. oldalán, de 1944-ben már nem tudta elkerülni, hogy Auschwitzba deportálják, ahol aztán elpusztult.) Úgy tűnik, a hirdetések kellő figyelmet keltettek, ugyanis 1932 nyarán Fehér több kisebb jelentőségű szórakoztatóművész társaságában szerepelt a Gellért fürdő egyik divatbemutatoján is, ahol fehér duplon rubát mutatott be a hullámmedence mellett. Ez fontos társasági esemény volt, ugyanis Horthyné és a polgármester is jelen voltak. (Az esemény részleteiről annak köszönhetően tudhatunk, hogy egy filmhíradó megörökítette, ld. Gárdos-Osvat 1987: no.7.)

Fehér Lili olcsó konfekció kötött ruhában a magazinhirdetésekben 1933-ban (Szinházi élet). A hirdetés kiemelt szövegrészében ez áll: „A legcsunyább pesti színésző FEHÉR LILI is csinos ebben a kötöttruhában."

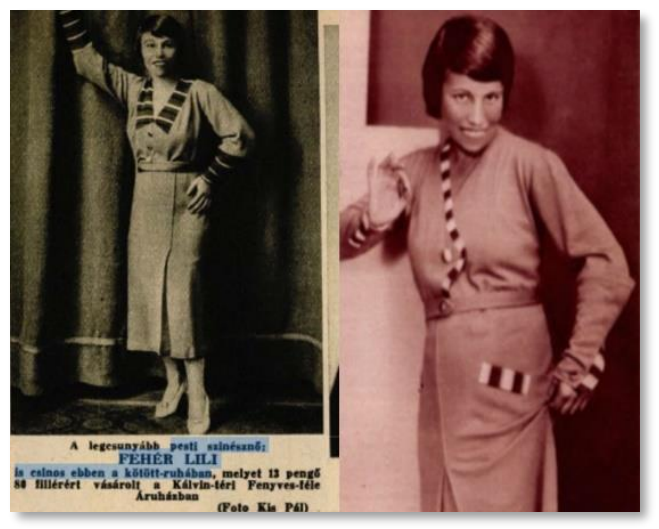

Egy 1933-as interjúban Fehér azt magyarázta a bestsellerszerző és újságíró Bródy Lilinek, hogy ha nem is volt valójában annyira csúnya, már az intézetben is a legcsúnyább hallgatónak számított. Állítása szerint azért ment bele ebbe a gúnynévbe, mert ahhoz, hogy az ember sikeres színésznő legyen, nem a tehetség a legfontosabb, hanem hogy az ember „leg” legyen valamiben, és ha valakirôl azt mondják, hogy csúnya squínésznō, az kárt okoz, de ha az a híre, hogy a legcsúnyább szinésznoó, az viszont müködik. Valójában valószínü, hogy Fehér ezt az önelnevezést mint hirdetési trükköt azokból a cikkekből vette, amiket 1930 szeptemberében a magyar lapokban olvasni lehetett a francia színésznőről, Polaire-ről (Émile Bouchart, 1879-1939), aki a nem sokkal korábban indult szépségversenyek mintájára azt javasolta, hogy most már egy csúfságkirálynö-versenyt is indítani kéne, és azt biztosan ő nyerné meg. Az interjúban Bródy belemegy Fehér játékába, és azt írja róla, hogy az interjú helyszínéül szolgáló kávéházban úgy jelent meg, mint akinek a „,csapzott fekete haja a szemébe lóg”. Bródy arról is megkérdezi Fehért, hogy a férfiak hogyan reagálnak erre a csúnyaságra, amire ő azt válaszolja, hogy „Nem törődöm a férfiakkal. Magányosan élek, nincs szükségem senkire”. De Fehér hozzáteszi azt is, hogy nem igazán magányos, mivel kutyákat tenyészt, és még Rajnai Gábor is (a híres színész, aki több filmben szerepelt 1945 előtt, mint bárki más) tőle szerezte a kutyáját, és azóta boldogan él. Bródy tovább 
kérdezgeti, hogy vajon hajlandó lenne-e helyet cserélni egy szépséges, de tehetségtelen színésznővel, amire Fehér azt válaszolja, hogy szívesebben lenne egy tehetséges kutya a színpadon, de az, amire igazán vágyik, az az, hogy sok jó szerepet kapjon, és hogy játszhasson egy Molière-darabban, mivel „a színpad jobb, könnyebb, mint az élet, higyje el!’. Egy későbbi, 1935-ös népszerű cikk szintén ugyanerre a „legszebb” kontra „legcsúnyább” témára fókuszált, amikor arra kereste a választ, hogy „Boldogít-e a szépség?”, aminek kapcsán a cikk Fehér mellett két korábbi Miss Hungáriát is meginterjúvolt, Simon Böskét és Fekete Máriát (Turcsányi 1933; a Miss Hungária-versenyről és a velejáró szépségkultuszról lásd Vasvári 2019).

1937-ben, köszönhetően a folytonos anyagi nehézségeknek és annak, hogy a második férje elhagyta, Fehér öngyilkosságot kísérelt meg, amiről egy lap a következő szavakkal tudósított: „,itt akarta hagyni cipőgombszemú, borzos, fekete puliját a Betyárt, meg a Peti Sándort, a hủtlen elvált férjet, azért, mert mindenki elhagyta, mert nem kapott szerepeket és mert anyagi gondjai voltak."

De Fehérnek annyira erős volt az öngúnyoló iróniája, hogy sikerült egy komikus, önmagát elítélő szöveggel előállnia még a saját öngyilkossági kísérletéről is:

Peti Sándor, aki a férjem volt, s akitől elváltam, pénteken átadta az általa egyegy hónapra megállapított tartásdijamat: tizenhárom pengót! Az egész ráment az öngyilkosságra! Vettem egy díszesebb hálóinget, hogy az legyen rajtam a koporsóban is. Ez öt pengó harminc fillérbe került. Egy tubus Phanodormnak két pengó tiz fillér volt az ára. Öt gramm aszpirint vettem egy pengőért és a Luxor kávéházban a trafikosfiúnál hatvan fillérért vásároltam levélpapirt... Amikor hazafelé indultam a kávéházból, összesen tizennégy fillér volt a retikülömben. („A legcsunyább színésznő öngyilkosságához,"Társadalmunk, 1937.10.08)

\section{Fehér Lili, Nem ér a nevem: Egy szökött zsidó naplója és Budapest, 1939-1945}

Az 1939-es második zsidótörvény után Fehért, a többi zsidó színésszel egyetemben, leparancsolták a színpadról, és csakis az OMIKÉ-nek, az Országos Magyar Izraelita Közmúvelődési Egyesületnek a Múvészakciója keretében léphetett színpadra. Ez zsidó színészek vállalkozása volt, 1939 és 1944 március 19-e közt több mint ötszáz programot szervezett, és így némi minimális egzisztenciát tudott biztosítani a színészek számára. Fehér, mivel az anyagi 
helyzete egyre kétségbeejtőbbé vált, és mivel remélte, hogy így némi pénzhez juthat, 1943-ban saját kiadásban megjelentetett egy vékony kötetet $A$ legcsinnyább szinésznó címmel, ami a Bródy Lili-interjút tartalmazta és öt további szöveget, amit színházzal foglalkozó fontos személyiségek írtak, köztük az egyiket Szép Ernő. Az, hogy Fehér házról házra járva árulta a könyvet nagyrészt olyan nőknek, akik felismerték - még jócskán 1944-ben is, és ezzel nagy veszélynek tette ki magát, később szerepet kapott abban, hogy Fehér és az anyja megmenekülhettek.

Az, hogy egy színésznő 1943-ban saját kiadásban megjelentet egy humoros kis könyvet, aminek később a túlélését köszönheti, korántsem annyira meglepő, mint gondolnánk. Amint azt Gajdó Tamás színháztörténész. kikutatta (2004), számos zsidó színész, aki többé nem állhatott színpadra, írt ekkoriban életrajzi emlékeréseket, részben valamiféle utolsó szalmaszálként, hogy így megéljen, részben, hogy fenntartsák az emberi méltóságukat. Ezeket a saját kiadású köteteket általában öt-tíz pengőért árulták, de a vásárlók időnként önként többet fizettek értük. Gajdó ezt az idôszakot az emlékirat korának hívja, ami az 1944-es német megszállással ért véget. Tizennégy múvészt sorol fel, köztük például a híres komikusművészt, Salamon Bélát, aki nem kevésbé volt ismert, és ugyanúgy nagyon nem volt szép, mint Fehér Lili, de aki hatalmas sikereket ért el. Ô volt a szerzője a Hej, szinmüvésærnek (1939), ami ezen életrajzi emlékezések sorát megnyitotta. A könyv tele volt szórakoztató anekdotákkal Salamon karrierjéről, és egyike volt a műfaj sikeresebb példányainak, a háború után több utánnyomást is megélt. Gajdó listáján nem szerepel Rózsahegyi Kálmánnak, Fehér korábbi, Nemzeti Színházbeli tanárának az 1942-ben megjelent mûve, a Zörög a haraszt: Vidám vadásztörténetek, amit mindmáig nevetséges módon vadászirodalomként katalogizálnak. Valójában egy kis könyv, olyan baljósan kétértelmú címmel, amilyen a hasonló mûvek legtöbbjének is volt, és amiben Rózsahegyi mulatságos anekdotákat közöl a színész- és írótársakkal a természetbe tett ünnepi kirándulásokról, amikre némelyikük a fegyverét is magával vitte, de természetesen nem lőtt vele.

Fehérnek $A$ legcsúnyább pesti szinésznoôje és egy másik színésznőnek, Pártos Erzsinek (1907-2000) a Köszönöm (1941) címú múve szerepelnek Gajdó bibliográfiájában, de Gajó nem tárgyalja őket. Pártos olyan szavakkal kezdi az emlékiratát, amiket akár Fehér is mondhatott volna: „Kedves közönség, kedves Barátaim! Ezerkilenszáznegyvenegy, szeptember! Elvesztettem a szerződésemet, kenyértelenül maradtam." Pártos, aki Pollacsek Bözsike néven született, a maga erőltetetten kedélyes visszaemlékezéseiben Fehér Lilihez hasonlóan azt hangsúlyozza, hogy tudta, hogy mivel nagyon alacsony és nem szép, ezért nem pályázhat vezető szerepekre, és tényleg nagyrészt csak kis szerepeket kapott, cselédnek állt parasztlányként. Fehér Lilihez hasonlóan volt néhány kisebb filmszerepe is, és, ami azt illeti, mindketten szerepeltek 
ugyanabban az 1937-es vígjátékban, a Mamiban, amiben Peti Sándornak, Fehér ex-férjének is volt egy nagyobb szerepe. Miközben Fehér Lili soha sem árulja el, hogy a képzelt „csúnyasága” mennyire a társadalom zsidó testről alkotott képét fogadta el, Pártos Erzsi folyton a szörnyű külsejére összpontosít, ami megakadályozta, hogy jó szerepekhez jusson, viszonylag részletesen leírja, hogy miként műttette meg a nagy és kampós zsidó orrát vagyis, a felismerhető faji megbélyegzést - azért, hogy így javítson a karrierlehetőségein, és hogy az új pisze orra sem juttatta jobb szerepekhez (cf. Gilman 1994). Végső soron azonban sikeresebb lett az élete, mint szegény Fehérnek, mivel a Vígszínház újra szerződtette 1945-ben, és itt dolgozott egészen addig, míg 1956-ban New Yorkba nem disszidált, hogy aztán 1958-ban visszajöjjön Magyarországra, és utána kiváló szakmai karriert fusson be élete végéig. Sajnos Fehér egyik fellépéséről sincs semmilyen ismert felvétel, de Pártos online meghallgatható.

Mivel Gajdó témája a zsidó színészek által 1943-ig megírt kényszermemoárok, ezért nem említi Fehér Lilinek az előzőnél jóval fontosabb második művét, a Nem ér a nevem: Egy szööött zsidó naplóját. Ez 1945 novemberében jelent meg, egy megindító, időnként ironikus emlékirat arról, Fehér hogyan bujkált hamis papírokkal 1944-ben Budapesten, a különféle álöltözeteket magára öltve.

Fehér nem egy Szép Ernő, akire folyton hivatkoznak az ironikus hangnemú Emberszag miatt, ami ugyanekkor jelent meg, de Fehérnek a viszontagságokról, éhezésről és folyamatos halálfélelemről szóló történetei - amik 1944-ből jóval nagyobb időszakot ölelnek fel, mint Szép munkája - tele vannak ahhoz hasonló keserüen önironikus humorral, mint amilyen a korábbi, saját magát kifigurázó legcsunyább szinésznō is volt, és amely humorral még a saját öngyilkossági kísérletéből is tréfát üzött. Maga a cím, a Nem ér a nevem játékosan fejezi ki azt, hogy hogyan kellett újabb és újabb szerepeket magára öltenie a bujkálás során.

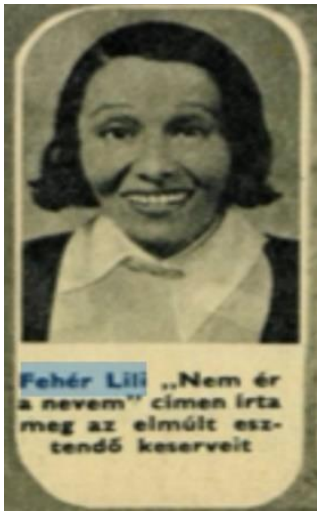

Fehér Lili 1946-ban (OMIKE)

A múvet egy meghitt gyerekkori emlékkel indítja arról, hogy amikor jómódú gyerekként játszott a parkban, miként szakította félbe szeretett játékát, a bújócskát a legközepén, amikor meglátta az apját közeledni, hogy odaszaladhasson hozzá, és megölelhesse. Amikor otthagyta a játékot, azt kellett kiáltania, hogy „nem ér a nevem”, ami, mint írja, a jelenben új értelmet nyert: „Remek játék. A felnőttek is szeretik, különössen az utóbbi időkben volt nagyon divatos. Mindenki a másik helyét akarja s akkor boldog, ha valaki 
kibukik (1)." Nehéz elmagyarázni a címet, ami fegyverszünetet jelent ebben a játszótéri játékban, és amit a legkülönfélébb helyzetekben használnak, például, ha szünetet kérnek, vagy meg kell kötni egy cipőfűzőt, a mosdóba kell menni, és így tovább. A „nem ér a nevem” egy bújócska játékban használatos kifejezés, ami ideiglenes védettséget nyújt az üldözöttnek. Ilyenkor vagy az egész játék leáll, vagy csak az adott játékos áll le egy időre. A jelentése az volt, hogy aki bejelentette, azt nem lehetett megfogni vagy leolvasni, tehát nem volt szabad beszámítani a játékba az illetőt úgy, mint akit a játék során találtak meg vagy olvastak le. A kifejezés szó szerinti értelemben azt jelenti, hogy „,nem vagyok, nem létezem”, de azt is jelenti, hogy „nem kaphatsz el”. Fehér fö álszemélyisége a bujkálás során a pisæk kos és büdös V arga Irma, akit kutyája és az anyja kísérnek. Fehér anyja hajlandó lett volna bemenni a gettóba, de végül, Fehér erősködésére, bujkálni kezdtek. Fehér a következőképpen írja le, hogy az élet, amiben a gyülölt Varga Irma szerepét kellett magára öltenie, miként kezdte ki benne annak érzését, hogy mi is a helye a világban:

Mikor az utóbbi időkben álmatlanul az ágyban feküdtem... és a félelemtől agyonhajszoltan, szinten enyhültem, a megaláztatásokra is gondoltam... akkor jutott eszembe, hogy nem ér a nevem. Hiszen az én nevem most Varga Irma, de az nem én vagyok, én Fehér Lili vagyok... de hát az nem lehet most... tegnap mesélték, hogy a Lehel téren agyonlőttek egy szökött zsidócsaládot... De én utálom Varga Irmát, mert piszkos és büdös és itt a Betyár kutya, az ágy előtt... éppen most nyög egyet... De hát a Betyár a Fehér Lilié... Istenem, hogy lehet azt kibírni, hogy három hete nem vetkőztem le... mert itt piszkos és kormos minden és egy részeges házmesterrel kell egy konyhában aludni.

Mint a magyar háborús naplók és emlékiratok legtöbbje, Fehér elbeszélése is Magyarország megszállásával indul 1944. március 19-én, egy vasárnapon. Leírja, hogy azon a napon hogyan maradtak el az előadások, hogyan nem jelentek meg az újságok, és hogy szomorú csend uralt mindent, továbbá, hogy a barátnőinek egyike, nagy felháborodására, azt javasolta neki, hogy el kéne altatnia a kutyáját, Betyárt. Úgy volt, hogy Fehér aznap egy kabarédarabban lép fel a Páva utcai templomban egyik színésztársával, Szabó Dezsővel (1913-1944), de ez nem történt meg, és Fehér itt azt is hozzáteszi, hogy a férfi ma a Klauzál téri közös sírban pihen. Fehér egy ideig még tovább házalt $A$ legcsunyább sziniész̨nő megmaradt példányaival, és a nők, akik felismerték, továbbra is vettek belőle. De nemsokára Fehért értesítette két csillagos úr a zsidó tanácstól, hogy három órán belül ki kell ürítenie a lakását. Ezt követően Fehérnek, az anyjának és a kutyának sokszor kellett költözniük vagy menekülniük, hogy új búvóhelyet találjanak a legszívfacsaróbb helyzetekben. Egy alkalommal Fehér, az álöltözetek mestere úgy menekült meg, hogy 
öregasszonynak álcázta magát slafrokban és ronda sálban, amit összekoszolt a padlón, az arcára pedig sárga színházi festéket tett, ugyanúgy festve ki magát, ahogy valaha a takaritónó szerepére készülve is tette. Noha júniusra a zsidókat már a nyilvános fürdôkből és más nyilvános helyekről is kitiltották, amik így mind zsidómentessé lettek, Fehér és az anyja mégis jártak a Dohány utcai fürdőbe, sőt, a Népfürdőbe és a Széchenyi fürdőbe is, ugyanis egyedül itt tudták levenni a ruháikat, és hetek után végre megmosakodni. De sosem mentek együtt, mert egyiküknek mindig vigyáznia kellett a kutyára. (Ez Soros Tivadarra emlékezteti az embert, akinek a Túlélni. Alarcban címmel 1966-ban eredetileg eszperantóul megjelent emlékirata szintén az álruhaviselésre összpontosít, és amiben Soros elmeséli, hogy miközben hamis papírokkal bujkált és nem viselt csillagot, hogyan járt kávéházba, színházba és naponta a Rudas fürdőbe.) Fehér fontolóra veszi, hogy megpróbál mentesitést szerezni, de végül egyszerủen csak letépi magáról a csillagot. Az álöltözetei annyira jól sikerültek, hogy amikor egy másik alkalommal egy nő az utcán erősködik, hogy feljelenti Fehért és az anyját mint zsidókat egy nyilasnál, akkor a nyilas nem hisz a nőnek, mivel Fehérék igazi pis₹kos cigányféléknek látszanak, és még a kutyájuk is velük van. A nő, aki megpróbálja feljelenteni Fehért, megkísérli lerántani a sálját, hogy megmutassa, Fehérnek milyen fekete és göndör is a haja, de amikor nem sikerül neki, akkor azt kezdi kiabálni az utca közepén, hogy „ezért veszítjük el a háborút”. Fehér még egy másik elképesztő jelenetben is eljátssza az öreg, elszegényedett nőt, amikor beviszik a Hársfa utcai rendőrségre, aztán szabadon engedik, de amikor épp távozik, az egyik öreg zsidó őrizetes odasúgja neki: „Lili, Lili, csak ezt ne tette volna!”.

Fehér emlékiratában számtalan kávéház, és különösen a híres Upor kávéház fontos szerepet játszik. Egy időben ő és az anyja az Uporban bújtak el éjszakára, és Fehér nagyon dicséri a drága jó asszony az Upornét, de az egyik pincért is, aki sok zsidó életét mentette meg. Ami érdekes, az az, hogy úgy beszél Upornéról, mintha nem lett volna ő is zsidó, talán azért, mivel még mindig múködtette a kávéházat, bár strómanokon keresztül. Az Upor az Andrássy út 25. szám alatt üzemelt, a Balettintézetben, szemben az Operával. A híres tulajdonos, Upor József 1937-ben halt meg. 1938-ban a tulajdonost már Upor Józsefné született Rosenfeld Olgaként azonosítják, de 1940-ben és 1942-ben már özvegy Upor Józsefnéként, a leánykori neve nélkül, ugyanakkor két stróman tulajdonostárssal együtt, ahogy aztán két évvel később is. Sok színész volt törzsvendég az Uporban, részben azért, mert Uporék fia, Upor Tibor (1904-1960) elismert színházi díszlettervező volt, aki Neményi Lili színésznőt vette feleségül.

Azt, hogy milyen volt az 1944-es év Budapestjének hangulata, tovább árnyalja, ha összehasonlítjuk Fehér Lili elbeszélését két párhuzamos jelenettel, amik szintén egy-egy kávéházban játszódtak, és két másik emberről szóltak, 
akik ugyanakkor voltak ugyanazon a helyen. Az egyik jelenet a híres zsidó színésszel, Básti Lászlóval (1911-1977) esett meg, aki Fehérhez hasonlóan hamis papírokkal, szabadon bujkált, és színházi álruhákat használt; a másik jelenet Marschalkó Lajos (1903-1968) egyik későbbi írásából származik. Marschalkó a német megszállás idején a Sztójay-kormány zsidóellenes intézkedéseit támogatta, aztán 1944-ben elmenekült, és később a távollétében itélték el háborús propaganda terjesztéséért. Básti egyik háborús idôkbeli álruhaöltése épp az Upor kávéházban történt. A jóképű szőke és kékszemű színész, aki nem látszott zsidónak, Londonban próbálta beindítani a karrierjét, miután a zsidótörvények leparancsolták a színpadról, de óvatlan módon visszatért Magyarországra, ahol, sokan másokhoz hasonlóan, ő is kipróbálta magát az írásban, ami az ő esetében konkrétan novellákat jelentett, nem pedig önéletrajzi anekdotákat. Számtalanszor behívták munkaszolgálatra, mígnem 1944-ben sikerült elmenekülnie, és egy Bódy László nevü debreceni virágkertész papírjaival bujkált, a józsefvárosi pályaudvaron dolgozott szenesemberként és rakodómunkásként is, és olyan jól sikerült elváltoztatnia a külsejét a megfelelő rongyos ing, használt cipő és szörnyű frizura segítségével, hogy a saját barátai sem ismertek rá. Egyik este 1944-ben, amikor érzelmileg már nem bírta tovább ezt az életet, nagy kockázatot vállalt azzal, hogy este 11-kor megjelent az Uporban a régi törzsasztalánál - miközben ugyanott volt az első emeleten a csendőrparancsnokság! Elegánsan felöltözve érkezett, estélyi köpenyben, fehér selyemsálban és frakkban, és leült az asztalhoz Upor Árpáddal, Neményi Lilivel és más barátokkal. Úgy érezte, hogy ha nem játszhat színpadon, akkor legalább fenn akarja tartani az érzést, hogy ember, és akár az életét is kockáztatva eljátssza legmegerőltetőbb szerepét az Uporban (Ézsaiás 1989). Bódy Lászlónak az Upor kávéházban előadott játékát a Selbstdarstellung kifejezéssel jellemezhetjük, ami az „én” nyilvános és színpadiasított megjelenítését jelenti, és amit a bécsi modernség megkülönböztető jegyeként tartanak számon, ahol is a város - jelen esetben a kávéház - az „én” megjelenítésének urbánus színpada (Gronberg 2001: 71). Bódy hajlandó volt az életét is kockáztatni azért, hogy, ha csak egy órára is, de visszanyerje az érzést, hogy saját maga lehet. Szerencsére a játéka sikeresnek bizonyult.

Hogy a maga teljességében értékelhessük a másik jelenetet Marschalkó Lajossal, szükséges, hogy merítsünk valamennyit a kritikai földrajz gondolataiból. Tim Cole a Holocaust City: The Making of a Jewish Ghetto [A bolokauszt városa: egy zsidó gettó születése] (2003) címú munkájában Budapest terének és idejének kulturális történelmérôl ír a holokauszt idején, és a teret olyan aktív tényezőnek tekinti, aminek segítségével végrehajtották a holokausztot. Cole rekonstruálta, hogyan jött létre a budapesti gettó, és a város térképeivel illusztrálta, hogyan osztották fel a nyilvános tereket úgy, hogy a 
gettósítás eltervezése és kivitelezése a várostervezés aktusává lett, ami fizikailag is átformálta a várost 1944-ben, amit ő „az utazások évének” nevezett. Amint azt Fehér írja az emlékiratában, az anyja hajlott volna arra, hogy beköltözzenek a gettóba, és Fehér volt az, aki amellett kardoskodott, hogy próbáljanak meg hamis papírokkal, szabadon bujkálni, ami végül a folyamatos álöltözék-viselést eredményezte, és azt, hogy egyik búvóhelyről költöztek a másikra. Ennek során az áldozatok térélménye és a túlélésük tényleg attól függött, hogy folyton kényszerűen vándoroltak, és akár egy térképre is fel lehetett volna rajzolni, hogy a gettón kiviüli bujkálásuk során merre mozogtak.

A zsidók kényszerű elköltöztetése része volt a Budapest zsidómentesítésére irányuló folyamatnak. De az is érdekes, hogy a fasiszta térbeli képzeletben a város topográfiájának zsidóellenes rasszista újrastrukturálása miért és hogyan is volt szükséges ahhoz, hogy ellensúlyozzák azt, amit beszennyezésnek vagy zsidó térfoglalásnak képzeltek. Úgy esett, hogy a épp rendelkezésünkre áll egy ilyen személyes és érzelmes vélemény, ami határozottan elüt Fehérnek a végzetes 1944. március 19-ről szóló beszámolójától, és ez Marschalkónak a huszonkét évvel későbbi nosztalgikus visszaemlékezése. Marschalkó, miután elmenekült Magyarországról, sosem tért vissza, de igen szaporán írt (időnként Mátray Lajos álnéven) a müncheni szélsőjobboldali emigráns sajtóba. Amikor 1968-ban meghalt, Wass Albert beszélt a temetésén. Marschalkó számtalan könyvet publikált, de a két „bestsellere”, a második a hungarista emigrácioban, a Kik árulták el 1918-ban Magyarországot? (1944) és a Világhóditók. Azigazi háborús bünösök volt (az utóbbi eredeti megjelenési ideje nem tisztázott, de egy úgynevezett második kiadás 1958-ban került kiadásra), amikben a zsidókat hibáztatta az I. és a II. világháborúért is.

Marschalkó Lajos két „bestsellere”, a Kik árulták el 1918-ban Magyarországot? és a Világhóditók
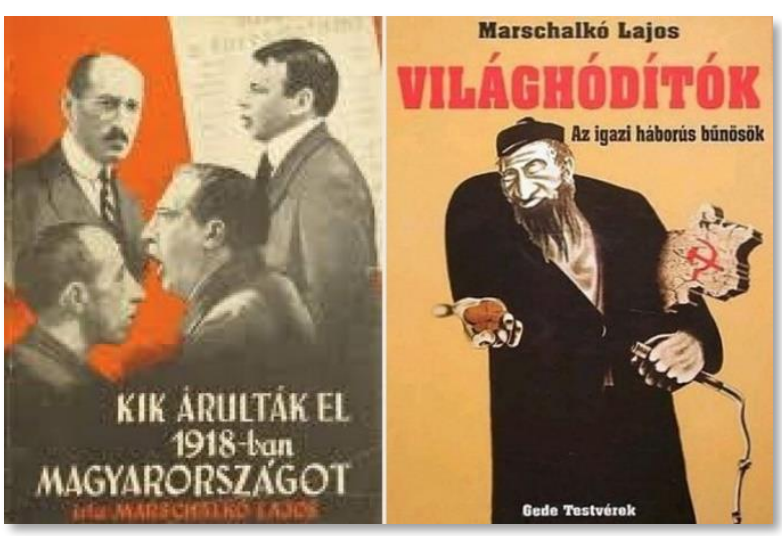

Fehér az emlékirata elején leírja, hogy március 19-én az első ösztönös gondolata az volt, hogy a New York kávéházba menekül, remélve, hogy ott találja a barátait, de senki sem volt ott: „a rendes társaságomat nem találom a 
kávéházban, egyáltalán kong az egész New York" (4)". Ezután felmegy az egyik közelben lakó törzsvendég lakásába, és látja, hogy mindenki ott gyülekezett össze, épp, mintha a kávéházban lennének, de rettenetes hangulatban. Marschalkó ugyanezen a délutánon nem a New Yorkba ment, hanem a zsidó tulajdonban lévő EMKE kávéházba az utca túloldalán, a Rákóczi út és az Erzsébet körút sarkán, ami mögött a hetedik kerületi zsidónegyed terült el, ami, mint írja, tele szokott lenni zsidókkal. Megkérdezte a főrarat, mi történt, aki azt válaszolta, hogy a németek megszállták Magyarországot, amire Marschalkó azzal az általa szellemesnek vélt replikával vágott vissza, hogy na akkor az igazi megszállók most elhagyták a kávéházat: „Az igazi megszállók kiürítették az EMKÉ-t”. Az üres kávéházi helyszín, ahol az ablak mellett foglalt helyet, és onnan nézte, hogy a német csapatok miként masíroznak a városközpontban, arra késztette Marschalkót, hogy felidézze, hogy „azok”, akik törzsvendégek voltak a New York kávéházban a túloldalon, hogyan ünnepelték a történelmi Magyarország végét, amiért most majd megfizetnek, mert „most majd elviszik az EMKE kávéház törzsvendégeit, hogy megtanítsák őket dolgozni” (Marschalkó 1964, a Kurucinfó weboldalon újraközölve 2013-ban; Kékesi 2017, 2018). Marschalkó itt Hitler első nagyobb, 1920-ban Münchenben tartott nyilvános beszédére utalt, amiben Hitler a gazdasági reform erényeit magasztalta, és azt állította, hogy a zsidók lealacsonyították és kizsákmányolták a munkát. A zsidók és a kemény munka ezen összeférhetetlensége aztán később a Mein Kampf, és még később a náci párt egyik fő tantétele lett. A zsidókat tehát megbélyegezték, mondván, kibújnak a fizikai munkavégzés alól, és nem hajlandók becsületes munkát végezni. Amibe Marschalkó nem ment bele az emlékeinek a felidézése során, az az a további ironikus mozzanat volt, hogy a német megszállás után a New Yorkból nemcsak eltűntek a zsidók, de a hely a Wehrmacht tisztjeinek a főhadiszállása is lett, és sok németbarát járt rendszeresen oda.

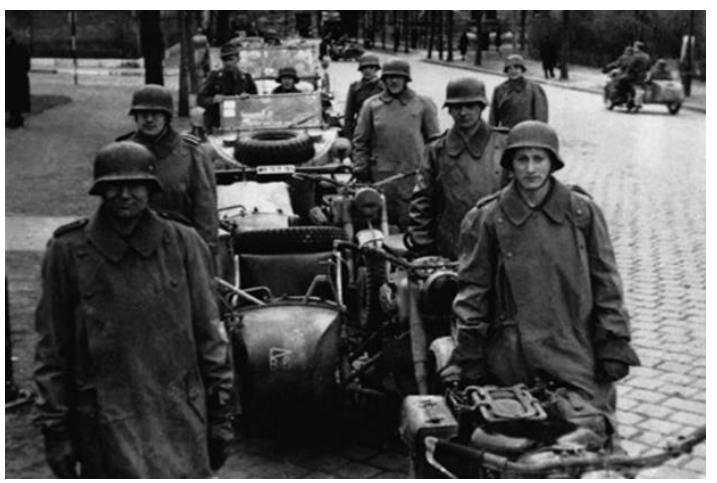

A Budapestet elfoglaló német csapatok látványa; ehhez hasonlót láthatott Marschalkó is 1944. március 19-én az EMKEbeli megfigyelőállásából

Fehér Lili, az anyja, sôt még a kutyájuk is túlélték a háborút, és Fehér azzal zárja az emlékiratát, hogy megismétli a cím szavait, mondván, „meg 
akarjuk tudni, hogy most már mit ér a nevem, mert én abból szeretnék megélni”. Sajnos bár a Nemzeti Színház igazgatója, Major Tamás 1946-tól szerződést kínált neki, tulajdonképpen egyáltalán nem kapott szerepeket. Depressziója és a folytatódó anyagi gondok miatt 1948 januárjában öngyilkosságot követett el, bár volt olyan lap, ami a halálát betegségnek tulajdonította. A Népsqava a 1948. január 25-ikei számában „kedvesen groteszkarcú” színésznőként emlékezett meg róla. Okosan megírt memoárja kellene, hogy emléket állítson az életének.

Mai szemmel nézve Fehér Lili memoárjának egyik meglepő vonása, hogy a történet benne teljességgel helyekhez kötött és személyes, azaz nincs benne szó azokról a híradásokról, hogy a zsidókat hogyan deportálják az ország többi részén, vagy éppen Budapesten. Fehér talán azért nem érez késztetést arra, hogy szóljon azokért, akik nem élték túl a háborút, mivel az anyja vele együtt életben maradt, és ez alól egyedül barátja és kabarébeli kollégája, dr. Szabó Dezső képez kivételt, akit Fehér már a könyv legelején megnevez, aztán újra a könyv végén is úgy, mint aki a gettóban halt meg bullamérgezésben, miközben temette a halottakat. Míg ilyen értelemben Fehér Lili memoárja befelé figyel, másrészről viszont nagyon is sokat elárul az ôt körülvevő világról, mivel a szerepjátszása során Fehér folyton erősen reflektált arra, hogy mit jelentett zsidónak vagy nem-zsidónak kinézni a nem-zsidó szem számára. A szöveg erőteljesen szólal meg Fehér sajátos hangján, és a nemileg kódolt [gendered] zsidó női testi élmények narratíváit helyezi előtérbe. Azt szemlélteti, hogy egy nő nehéz életét hogyan formálták annak metszéspontjai és az abból adódó halmozott trauma, hogy ugyan gyerekként jómódból indult, de színésznőként sokat küszködött és egyre rosszabb körülmények közé jutott, hogy krónikus depressziója volt, és átélt egy történelmi katasztrófát is, ami csak még tovább traumatizálta. Legfontosabb szerepét 1944-ben formálta meg a túlélés játékában, de a felszabadulás után nem volt képes arra, hogy újrastrukturálja női szakmai identitását.

Fehér Lili memoárja és mindazon nők memoárjai, akiknek az életét és írásműveit tanulmányozni fogom, egy kivételes pillanatot örökítenek meg a történelemben, és ott rejlik bennük a lehetőség, hogy gazdagítsák a narratívákat arról, amit akkoriban vészkorsz̧aknak hívtak, illetve az azt közvetlenül követő időszakról. Ezek a mûvek abban is segítenek, hogy elfeledett történeteket és elfeledett életeket állítsunk helyre a történelmi emlékezet számára. 


\section{Felhasznált irodalom}

Bródy Lili. 1933. "A legcsunyább pesti szinésznő." Színháąi Élet 1933.4: 42-43.

Czibor, János. 1945. "Az új magyar könyvtermelés mérlege." Valóság 1-2: $67-$ 70.

Deák-Bárdos, György. 1933. "Filmszemle." Magyar Kultuira. Társadalmi és tudományos szemle 8.1-12: 561-562.

Ézsaiás Erzsébet. 1989 "Básti: Többször kezdtem pőrén elölről az életemet," Népszabadság feb 28:7.

Fehér, Lili. 1945. Nem ér a nevem: egy szö̈ö̈tt ssidó naplója. Budapest: saját kiadás.

Földes, Anna. 2007. "Elmesélt női történetek." Élet és Irodalom szept. 14 https://www.es.hu/cikk/2007-09-16/foldes-anna/elmeselt-noitortenetek.html

Gaál, György. 2011. "'Én jót akartam.' Ligeti Ernő pályaképe." Korunk 11. november: 91-104.

Gajdó, Tamás. 2004. "Nem véletlenül történt: zsidó színházművészek emlékiratai 1939 és 1943 között" Jelenkor 47: 538-544.

Gárdos, Péter - Osvát, András. 1987. "Filmhamisítvány - filmnovella 19781979. Mozgó Világ 7: 21-40.

Gilman, Sander L. 1994. "The Jewish Nose: Are Jews White? Or, the History of the Nose Job." The Other in Jewish Thought and History: Construction of Jewish Culture and Identity. Laurence J. Silberstein and Robert Cohn, eds. New York: NY University Press, 364-401.

Gronberg, Tag. 2001. "The Inner Man: Interior and Masculinity in Early Twentieth-Century Vienna." Oxford Art Journal (24)1: 67-88.

György, Péter. 2010. "'A láger sors'. Géra György Terelöút." Jelenkor 2010.12.01: 1350-1360.

Jablonczay, Tímea. 2019. "Hivatalos amnézia és az emlékezés kényszere. A holokauszt női elbeszélései az 1960-as években." Múltunk 2: 78-110.

Kálmán, C. György. 2007. A túlélés poétikai problémái. A magyar irodalom történetei. Szegedy-Maszák Mihály, Veres András, szerk. 3. kötet. Budapest, Gondolat, 418-427.

Kaplan, Marion. 2019. "Did Gender Matter During the Holocaust? Jewish Social Studies (24)2: 37-56. 
Kékesi, Zoltán. 2017. "Ébredő emlékezet. Egy antiszemita képkultusz története (1944/1964)." Apertura 2017 Tél. https://www.apertura.hu/2017/tel/kekesi-ebredo-emlekezet-egyantiszemita-kepkultusz-tortenete-19441964/

Kisantal, Tamás. 2018. “A zsidóüldözés ábrázolása az 1950-s évek magyar irodalmában.” Mesterek és tanítványok, Szerk. Czeferner Dóra, Böhm Gábor, Fedeles Tamás. Pécs: PTE-BTK TDT, 165-189.

Kisantal, Tamás. 2016. "Holokausztirodalom Magyarországon: Módszertani megjegyzések egy magyar holokausztirodalom-történethez." AETAS (31) 4: 116-134.

Kovács, András. 1984. "A zsidókérdés a mai magyar társadalomban." Zsidóság az. 1945 utáni Magyarországon. Paris: A Magyar Füzetek Kiadása: 3-14.

Laczó, Ferenc. 2014. "Alvilági társasutazások keresztúti állomásai: a háborús évekbeli üldöztetettség korai elbeszéléseiről." Betekintô" 2014.3http://epa.niif.hu/01200/01268/00031/pdf/EPA01268_bete kinto_2014_3_05.pdf

Márkus, Béla. 2015. "Ki beszél győzelemről? Túlélni - ez minden." Hitel április: 54-68. http://www.hitelfolyoirat.hu/sites/default/files/pdf/07-markus.pdf

Pándi, Pál. 1954. "A felszabadulás ábrázolása regényeinkben. Uó: Viták és kritikák. Budapest: Szépirodalmi, 156-170.

Pesti Napló képes melléklete 1932. 10.02.

Petri, László. 2015. "A zsidóság helyzete a Rákosi-korszak első felében." Magyar Szemle 30:5-6. http://www.magyarszemle.hu/onlinecikk/20160831_a_zsidosag_helyzete_a_rakosikorszak_elso_feleben_online_

Soros, Tivadar. 2018. Túlélni. Álarcban. Nácivilág Magyarországon. Szibériai Robinsonok. Szerk. Kőbányai János, Budapest: Múlt és Jövő.

Sundquist, Eric J. 2012. "Silence Reconsidered. An Afterword." After the Holocaust: Challenging the Myth of Silence. David Cesarini and Eric J. Sundquist, eds. London: Routlege, 202-212.

Szécsényi, András. 2017. "Holokauszt-reprezentáció a Kádár-korban. A hatvanas évek közéleti és tudományos diskurzusának emlékezetpolitikai vetületei." Tanulmányok a holokausztról. 8. kötet. Szerk. Randolph L. Braham. Budapest: Múlt és Jövő, 291-329.

Turcsányi, Gyula. 1935. "Boldogít-e a szépség? Magyarország dec. 25: 23. 
Vasvári, Louise O. 2019. „Simon Böske, Miss Hungária és Miss Európa, 1929, faj és nemzeti identitás a két világháború közti Magyarországon.” Múlt és Jövő 2: 65-93.

Vasvári, Louise O. 2017. "Sárga csillag és mindennapi élet szélsőséges körülmények között: budapesti naplók 1944-45-ből." TNT: Interdisciplinary eJournal of Gender Studies (7)1: 126-147 http://tntefjournal.hu/vol7/iss1/vasvari.pdf

Vasvári, Louise O. 2016. "Életírás, társadalmi nemek és trauma." TnT. Interdisciplinary eJournal of Gender Studies 6.2 (2016): 150-197 http://tntefjournal.hu/vol6/iss2/vasvari.pdf

Vasvári, Louise O. 2012. "Annak átka, ha valaki művelt, zsidó és nő: holokauszt-túlélő orvosnők életírása.” Múlt és Jövô 1: 10-34.

Wieviorka, Annette. 1998. L'ère du témoin. Paris: Plom.

Zombory Máté. 2015. "Magyar Golgota. Politikai közösség és múltreprezentáció 1945 után." Szociológiai S zemle (25)1: 66-88. 